\title{
STIMULATION OF CONCEPTION IN COWS BY CHORIONIC GONADOTROPIN AND SYNTHETIC GONADOTROPIN-RELEASING HORMONE ADMINISTRATION
}

\author{
E. KUDLÁČ, Z. VLČEK, M. VRTĚL, J. VYČÍTAL \\ Department of Farm Animals Reproduction and Surgery, University of Veterinary Science, \\ 61242 Brno
}

Received March 1, 1981

\begin{abstract}
Kudláč E., Z. Vlček, M. Vrtěl, J. Vyčital: Stimulation of the Conception in Cows by Chorionic Gonadotropin and Synthetic Gonadotropin-Releasing Hormone Administration. Acta vet. Brno, 51, 1982: 91-97.

Effect of HCG and gonadotropin-releasing hormone (Gn-RH) administration on the conception rate in 792 cows in large-scale units was investigated. A total of 431 cows were treated with 1500 IU (93 head) or 3000 IU (203 head) of HCG, or $5 \mu \mathrm{g}$ nonapeptide Gn-RH (46 head), $10 \mu \mathrm{g}$ nonapeptide Gn-RH (63 head) or with $50 \mu \mathrm{g}$ of dekapeptide $\mathrm{Gn}-\mathrm{RH}$ ( $26 \mathrm{head}$ ). A group of 361 simultaneously inseminated cows served as control.

In all treated groups a conception rate by 3.29 to $24.41 \%$ higher was obtained as compared to the controls. The best results were found after treatment with $10 \mu \mathrm{g}$ of nonapeptide $\mathrm{Gn}-\mathrm{RH}$ at the second and first insemination $(71.42 \%$ and $62.16 \%$, respectively) and with 3000 IU of HCG at the second and first insemination (67.64\% and $67.44 \%$, respectively).

Stimulation of conception in sows with HCG or Gn-RH seems to be another tool in the improvement of reproductive performance of cows in large-scale production units.
\end{abstract}

Cattle, insemination, conception rate, reproductive performance.

A rather low conception rate of cows in large-scale units results, for the most part, from frequent disturbances of ovulation and incorrect timing of artificial insemination. The fact that the immediate cause of a delayed or even absent ovulation in cattle is above all a low plasma level of luteinizing hormone $(\mathrm{LH})$ offers a possibility of substitution therapy with preparations containing $\mathrm{LH}$ or hypothalamic gonadotropin-releasing hormone $(\mathrm{Gn}-\mathrm{RH})$. Production of synthetic $\mathrm{Gn}-\mathrm{RH}$ and a good market supply of HCG have promoted a number of workers to study the effects of a single application of such substances on the conception rate improvement in breeding cows.

A conception rate by $19.6 \%$ higher as against the controls was achieved in cows by i.m. administration of $500 \mathrm{IU}$ of Gonabion (HCG) given in the time interval of 24 hours before up to 24 hours after insemination (Knoblauch 1975). Similar results have been reported by Simon (1977).

A beneficial effect of $\mathrm{Gn}-\mathrm{RH}$ treatment in cows with delayed ovulation and higher conception rates in artificially inseminated cows were reported by Sali and Delfanti (1976) and Yamauchi et al. (1979). Improved conception rate by $13.1 \%$ as against controls was found in 197 German Red Pied cows treated with 100 or $250 \mu \mathrm{g}$ of Gn-RH (Ehlers 1977). The effect of treatment in cows once or several times unsuccessfully inseminated accounted for $19 \%$ in animals treated with $100 \mu \mathrm{g}$ and $23 \%$ in those treated with $250 \mu \mathrm{g}$ of $\mathrm{Gn}-\mathrm{RH}$ as against the controls. In these, a positive correlation was found between the insemination interval length and conception rate whereas in cows treated with Gn-RH substantially smaller differences occurred. Similar data presented Goldbeck (1976).

Stimulating results of treatment with HCG and Gn-RH (Kudláč et al. 1980) have lead us to study in more detail the timing and time-related stimulation of ovulation in cows as affected by hormonal treatment aimed at improved reproductive performance. 


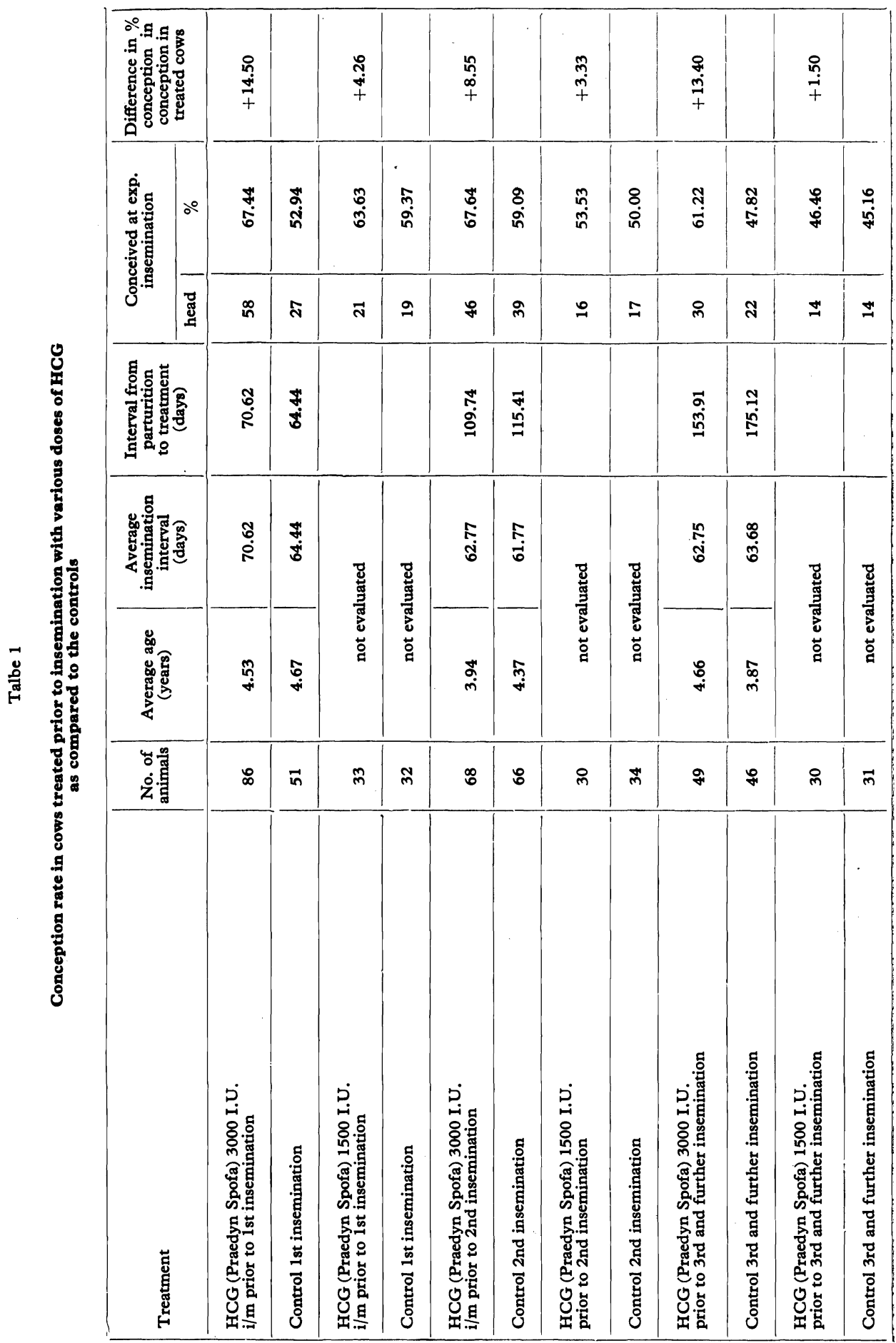




\section{Materials and Methods}

The experiments were carried out on several farms with similar husbandry systems and performance of the animals. A total of 792 cows were employed. The animals were divided in groups according to the number of inseminations performed and according to the treatment. Only cows showing a normal heat and physiological status of the reproductive organs were included in the study. At first, second, third or a further insemination a single i.m. injection of the respective preparation was given to 431 cows as follows: 93 cows were treated with 1500 IU of HCG (Praedyn Spofa), 203 were treated with 3000 IU of HCG (Praedyn Spofa), 46 cows were given Gn-RH at a dose of $5 \mu \mathrm{g}$ of nonapeptide LHRF (Lutal forte Hoechst), 63 were given the same drug at a dose of $10 \mu \mathrm{g}$, and 26 cows were treated with Gn-RH at a dose of $50 \mu \mathrm{g}$ (dekapeptide LHRF Lutal Hoechst). A group of simultaneously inseminated cows served as a control of the treatment effect. In both treated and control groups, detailed records were kept on the estrus character, reproduction parameters and performance of the animals. The external symptoms of estrus, at which time the cows were examined, were mostly marked with a usual amount and quality of mucus. In several cows less pronounced symptoms of estrus were seen with changes in the amount and consistency of the cervical mucus. The cows were usually inseminated once, at average intervals from parturition to treatment at first insemination accounting for 60.50 to 70.62 days, at second insemination 108.60 to 109.74 days, at third or following insemination 153.91 to 299.62 days.

\section{Results}

The results of the present study are encouraging in that higher conception rates were reached in all treated groups of cows with any of the above mentioned preparations as against the controls (Table 1). A high conception rate was found in cows treated with 3000 IU of HCG prior to the second and first insemination (67.64 \% and $67.44 \%$, respectively), representing an improvement of $8.55 \%$ and $14,5 \%$ as against the controls. Worse results were obtained in cows treated prior to the third insemination although in this group, too, an improvement of $13.4 \%$ as against the controls was found. Less improvement of the conception rate was obtained after treatment with 1500 IU of HCG $(1.5 \%$ and $4.26 \%$, respectively).

Similar results were observed in cows treated with Gn-RH (synthetic nonapeptide or dekapeptide) as indicated in Table 2. The highest conception rate was found in animals treated with higher doses of nonapeptide $\mathrm{Gn}-\mathrm{RH}$, particularly at the second and first insemination $(71.42 \%$ and $62.16 \%$, respectively) with a remarkable improvement as against the controls. A less pronounced effect was found in cows treated with $50 \mu \mathrm{g}$ of dekapeptide Gn-RH. In this group only $50 \%$ of cows conceived.

In Table 3 the results of experimental application of HCG and Gn-RH are summarized. Evaluation of the results irrespective of the sequence of insemination revealed the highest conception rate after treatment with 3000 IU of HCG and $10 \mu \mathrm{g}$ of nonapeptide Gn-RH $(66.0 \%$ and $60.31 \%$, respectively). The greatest differences as against the controls were found after treatment with the above-mentioned drug $(16.08 \%$ and $24.41 \%)$. Improvement of the conception rate in all treated groups averaged $11.44 \%$ as against the controls.

In Table 4, the relationship between the insemination sequence and conception rate is documented. These data clearly show the highest conception rate in cows treated prior to the first and second insemination $(63.72 \%$ and $63.63 \%$, respectively), surpassing that of the control animals after simultaneous insemination by $13.4 \%$ and $10.91 \%$. Cows treated prior to the third and following insemination had a conception rate by $8.04 \%$ higher than the respective control animals. Nevertheless, their conception rate was still by $10.89 \%$ and $10.80 \%$ lower than that of cows treated before the first and second insemination. 


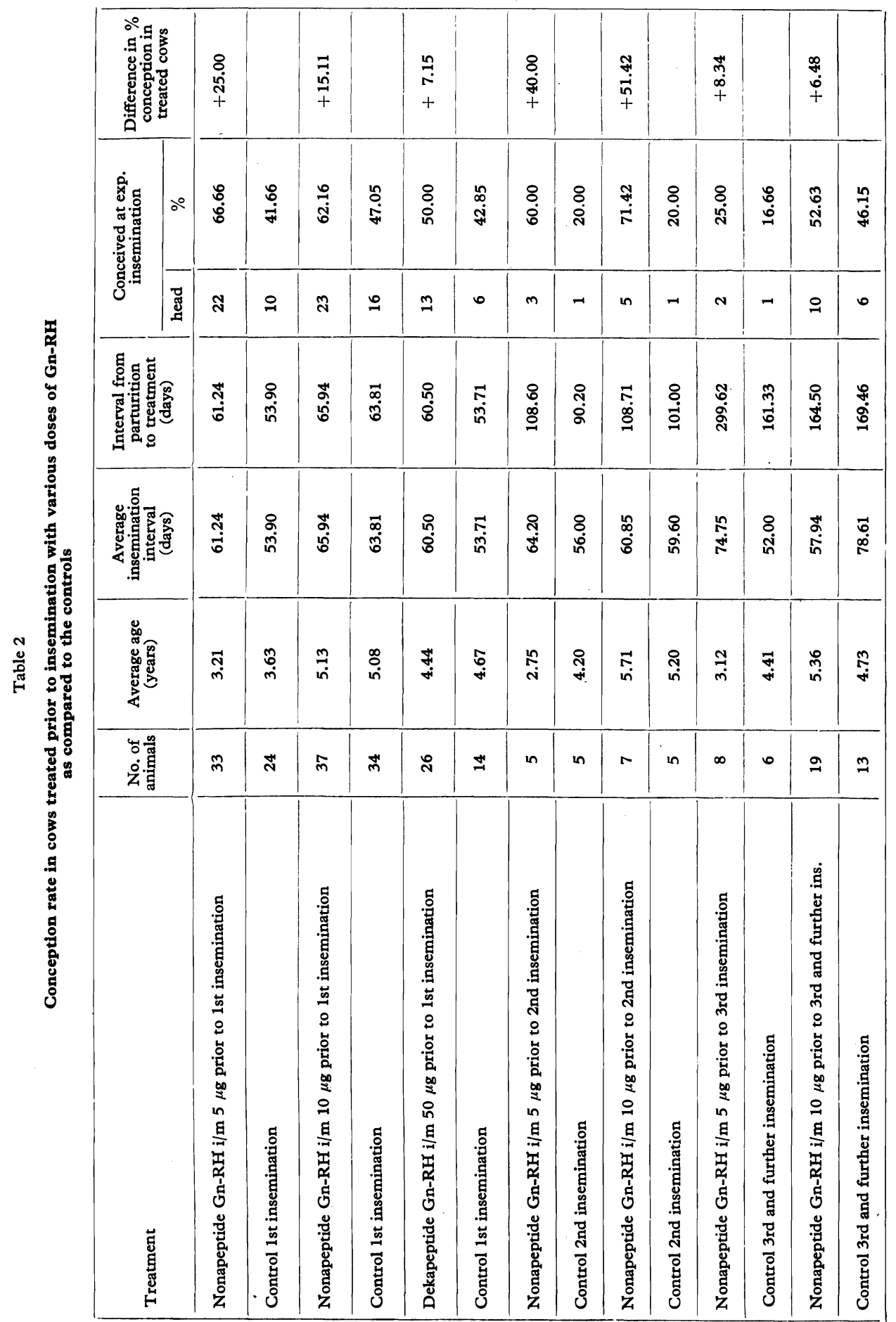




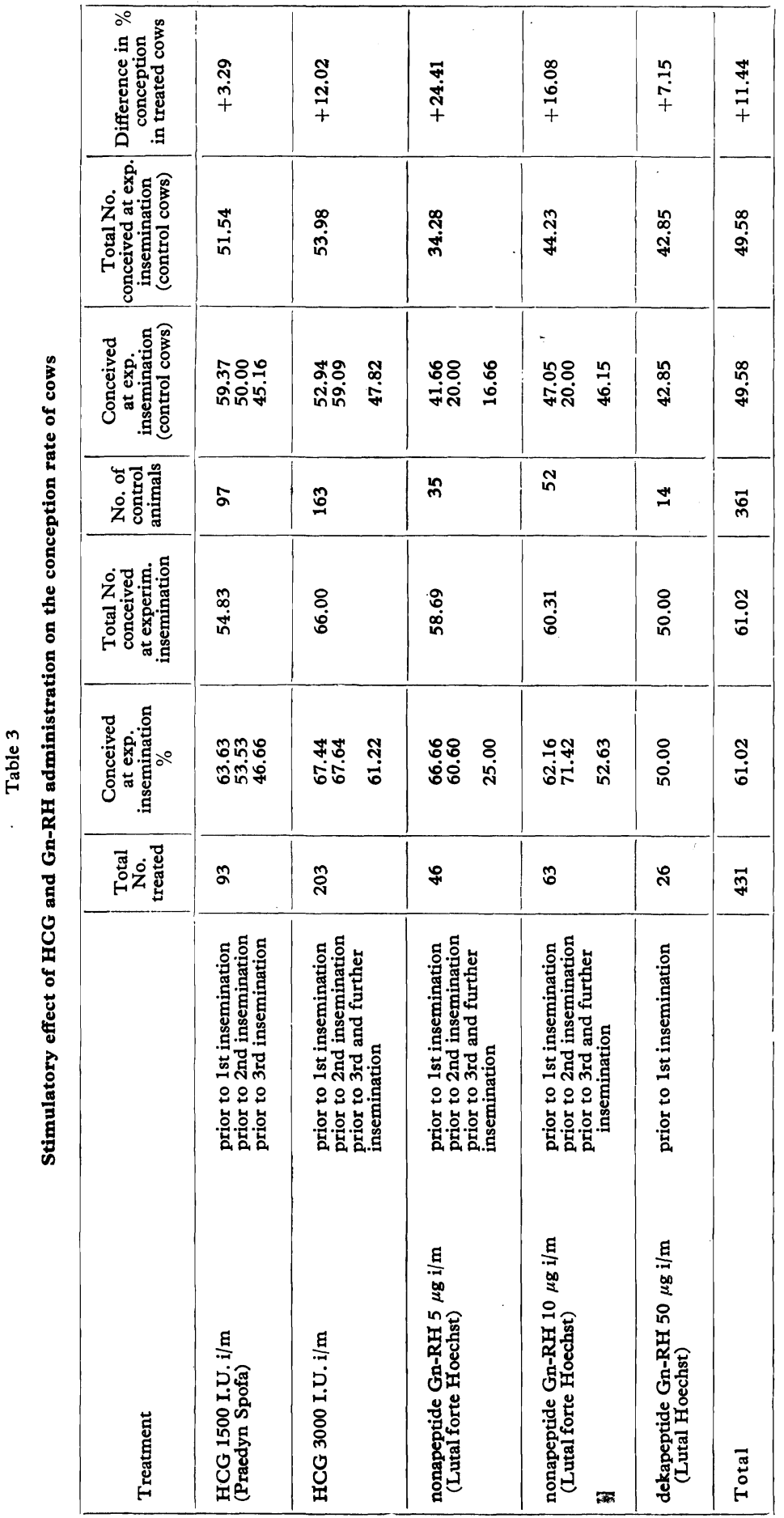


Table 4

Sequence of inseminations as related to the conception rate of cows treated with HCG and Gn-RH

\begin{tabular}{|c|c|c|c|c|c|c|}
\hline \multirow{2}{*}{$\begin{array}{l}\text { No. of } \\
\text { insemination }\end{array}$} & \multicolumn{2}{|c|}{ Treated cows } & \multicolumn{2}{|c|}{ Control cows } & \multirow{2}{*}{$\begin{array}{c}\text { Difference in \% } \\
\text { conception in } \\
\text { treated cows }\end{array}$} & \multirow{2}{*}{$\begin{array}{l}\text { Difference in } \% \\
\text { conception in } \\
\text { cows after 1st } \\
\text { and 2nd-3rd } \\
\text { insemination }\end{array}$} \\
\hline & No. & conceived & No. & conceived & & \\
\hline $\begin{array}{l}\text { First } \\
\text { Second } \\
\text { Third and further }\end{array}$ & $\begin{array}{l}215 \\
110 \\
106\end{array}$ & $\begin{aligned} 137 & =63.72 \\
70 & =63.63 \\
56 & =52.83\end{aligned}$ & $\begin{array}{r}155 \\
110 \\
96\end{array}$ & $\begin{array}{l}78=50.32 \\
58=52.72 \\
43=44.79\end{array}$ & $\begin{array}{r}+13.40 \\
+10.91 \\
+8.04\end{array}$ & $\begin{array}{l}\overline{-}_{0.09} \\
-10.89\end{array}$ \\
\hline Total & 431 & $263=61.02$ & 361 & $179=49.58$ & ó +11.44 & \\
\hline
\end{tabular}

\section{Discussion}

A favourable effect of administration of luteinizing substances (HCG and Gn-RH) on the conception rate in cows is demonstrated by the present results. This effect lies in fortification of the LH level in the blood and its substitution in cows likely to have a delayed or absent ovulation. Thus an increased LH level provides a timely maturation of the follicle and ovulation followed by development of a functional corpus luteum able to maintain pregnancy.

Our results further demonstrated the effect of the sequence of inseminations; the highest conception rate was found in cows treated prior to the first and second insemination. A similar trend was observed in control cows, too. Slight differences in conception rates of cows treated at first and second insemination can be explained by the fact that with prolonged postpartum period (up to 90-100 days) the conception rate tends to increase anyway (Salisbury and Van Demark 1961). A lower conception rate in cows after the third and further inseminations is undoubtedly related to possible pathological conditions of the reproductive organs and disturbances of the cycle.

The results were also influenced by the dose of the preparation used for treatment. Best results were obtained with 3000 IU of HCG and $10 \mu \mathrm{g}$ of nonapeptide Gn-RH.

\section{Stimulace koncepce krav choriovým gonadotropinem a syntetickým Gn-RH}

U 792 krav ve velkochovech byl zkoumán vliv intramuskulární aplikace HCG a Gn-RH před provedením inseminace na úroveň zabřezávání. $431 \mathrm{krav}$ bylo před první, druhou, třetí, popřipadě další inseminací ošetřeno 1500 nebo $3000 \mathrm{j}$. HCG, $5 \mu \mathrm{g}$ nebo $10 \mu \mathrm{g}$ nonapeptidu Gn-RH, $50 \mu \mathrm{g}$ dekapeptidu Gn-RH. Jako kontrola bylo hodnoceno 361 paralelně inseminovaných krav.

Ve všech skupinách ošetřených krav byla dosažena lepší úroveň zabřezávání než u kontrol a to o 3,29-24,41\%. Nejlepší koncepce byla zjištěna při použití $10 \mu \mathrm{g}$ nonapeptidu Gn-RH při druhé a první inseminaci $(71,42 \%$ a $62,16 \%$ ) a $3000 \mathrm{j}$. HCG při druhé a první inseminaci $(67,64 \%$ a $67,44 \%)$.

Stimulace koncepce krav HCG nebo Gn-RH představuje jednu $z$ dalších možností zlepšení výsledků reprodukce ve velkochovech. 


\section{Стимуляция зачатия коров хориальным гонадотропином и синтетическим Gn-RH}

У 792 коров скотоводческих ферм проводились исследования влияния внутримышечного применения HCG и Gn-RH перед проведением искусственного осеменения до уровня забеременения. 431 корова подавали перед первым, вторым, третьим или последующими искусственными осеменениями 1500 или 3000 единиц HCG, 5 ng или $10 \mathrm{ng}$ нонапептида Gn-RH, 50 ng декапептида Gn-RH. В качестве контрольной группы проводилась оџенка 361 паралельно осемененной коровы.

У всех групп коров было достигнуто лучшего уровня забеременения чем у контрольной группы, а именно на $3,29-24,41 \%$. Самое лучшее зачатие было установлено при применении $10 \mathrm{ng}$ нонапептида Gn-RH при втором и первом осеменениях $(71,42 \%$ и $62,16 \%)$ и 3000 единиц НCG при второй и первой осеменениях $(67,64 \%$ и $67,44 \%)$.

Стимуляция зачатия коров HCG или Gn-RH представляет собою одну из возможностей улучшения результатов репродукции в скотоводстве.

\section{References}

EHLERS, H.: Untersuchungen über den Einfluss eines syntethischen Gonadotropin - Releasing - Hormons $(\mathrm{Gn}-\mathrm{RH})$ auf die Besamungsergebnisse bei Kühen. Thesis Hannover 1977, 64 p.

GOLDBECK, U.: Verbesserung der Erstbesamungsergebnisse bei Rindern durch Gonadotropin-Releasing-Hormone (Gn-RH). Thesis Hannover 1976, 66 p.

KNOBLAUCH, H.: Gonabion-Applikation im besamungsnahen Zeitraum. Mh. Vet. Med., 30, 1975: 190-192.

KUDLAČ, E. - VLČEK, Z. - VRTĚL, M.: Stimulace koncepce krav. Sborník ref. věd. konf. s mezinárodní účastí Brno 4.-6.6.1980, p. 14.

SALI, G. - DELFANTI, F.: L'impiego del GN-RH (Gonadotropin-Releasing-Hormone) nel trattamento dell'ovulazione ritardata e per migliorare i risultati della F. A. Atti della Soc. Ital. di Buiatria, 8, 1976.

SALISBURY, G. W. - van DEMARK, N. L.: Physiology of Reproduction and Artificial Insemination of Cattle. W. H. Freeman \& Co., San Francisco \& London, 1961, 639 p.

SIMON, K.: Graviditätsergebnis nach HCG-Injektion zum Zeitpunkt der Besamung bei wiederholt umrindernden Kühen. Tierärztl. Umschau, 32, 1977: 266-270.

YAMAUCHI, M. - KARIYA, T. - TANAKA, M. - SASAKI, N.: Effects of synthetic LH-RH on Ovulation in the Cow. 1. Induction of Ovulation in Postpartum Cows and Cows with Ovulation Failure. Jap. J. Anim. Reprod., 25, 1979: 12-16. 